\title{
FCERIA gene promoter polymorphisms: Lack of association with aspirin hypersensitivity in whites
}

\section{To the Editor:}

Recently, Bae et al $^{1}$ described the association between 2 FCERIA gene promoter polymorphisms $(-95 \mathrm{~T}>\mathrm{C}$ and $-344 \mathrm{C}>\mathrm{T}$ ) and aspirin-intolerant chronic urticaria (AICU). They also reported the carriers of the $-344 \mathrm{~T}$ allele to have a higher total serum IgE levels than -344 CC homozygotes. ${ }^{1}$ This finding replicated indirectly a previous observation by Shikanai et al, ${ }^{2}$ who noticed the $\mathrm{CC}$ genotype of the $-344 \mathrm{C}>\mathrm{T}$ polymorphism to be more common in whites, but not in African Americans, with asthma with lower IgE levels. The $-95 \mathrm{~T}>\mathrm{C}$ polymorphism was previously associated with atopic dermatitis in a Japanese population. ${ }^{3}$

In our recent work, we confirmed the presence of both $-95 \mathrm{~T}>\mathrm{C}$ and $-344 \mathrm{C}>\mathrm{T}$ FCERIA gene polymorphisms in a representative white Polish population. ${ }^{4}$ The $-344 \mathrm{C}>\mathrm{T}$ polymorphism frequency in our subjects was similar to that reported by Shikanai et $\mathrm{al}^{2}$ in American whites; however, the $-95 \mathrm{~T}>\mathrm{C}$ polymorphic variant was much more common than in a Japanese ${ }^{3}$ or Korean ${ }^{1}$ population. The frequency of the $-344 \mathrm{C}>\mathrm{T}$ variant allele was similarly much higher in Poles ${ }^{4}$ than in Koreans. ${ }^{1}$ Association of the -344TT genotype with higher total serum IgE levels in allergic patients ${ }^{4}$ was evident in our study and agreed with results of American ${ }^{2}$ and Korean ${ }^{1}$ studies.

However, in contrast to Bae et al, ${ }^{1}$ we did not find any association between these 2 FCERIA gene polymorphisms and aspirin hypersensitivity. ${ }^{4}$ This inconsistency could be explained by a different composition of our patient group, which included both patients with asthma and urticaria, ${ }^{4}$ and by interracial differences between whites and Asians. Moreover, unlike Bae et al, ${ }^{1}$ we found both single-nucleotide polymorphisms to be in a complete linkage disequilibrium, with only 3 haplotypes present in the subjects studied: $-344 \mathrm{~T} \mid-95 \mathrm{~T}$, $-344 \mathrm{C} \mid-95 \mathrm{~T}$ and $-344 \mathrm{C} \mid-95 \mathrm{C}{ }^{4}$ Relatively low frequencies of both polymorphisms in Koreans along with interference of the $-344 \mathrm{C}>\mathrm{T}$ variant on total serum $\mathrm{IgE}$ could result in more frequent presentation of the AICU phenotype among carriers of the variant $-344 \mathrm{~T}$ allele. ${ }^{1}$

The association between the $-344 \mathrm{TT}^{4}$ or $-344 \mathrm{TT} / \mathrm{TC}$ genotype $^{1}$ with elevated total serum IgE levels appears to be replicated in different ethnic groups. The clinical 
consequences of this functional polymorphism within the FCERIA gene, including aspirin hypersensitivity, require further research.

Marek Sanak, $M D, P h D$

Daniel P. Potaczek, MD

Lucyna Mastalerz, $M D, P h D$

Ewa Nizankowska, $M D, P h D$

Andrew Szczeklik, MD, PhD

From the Department of Medicine, Jagiellonian University School of Medicine, Krakow, Poland. E-mail: mmszczek@cyf-kr.edu.pl.

Disclosure of potential conflict of interest: The authors have declared that they have no conflict of interest.

Editor's note: There is no accompanying reply to this correspondence.

\section{REFERENCES}

1. Bae JS, Kim SH, Ye YM, Yoon HJ, Suh CH, Nahm DH, et al. Significant association of FceRI $\alpha$ promoter polymorphisms with aspirin-intolerant chronic urticaria. J Allergy Clin Immunol 2007;119:449-56.

2. Shikanai T, Silverman ES, Morse BW, Lilly CM, Inoue H, Drazen JM. Sequence variants in the FceRI alpha chain gene. J Appl Physiol 2002;93:37-41.

3. Hasegawa M, Nishiyama C, Nishiyama M, Akizawa Y, Mitsuishi K, Ito T, et al. A novel $-66 \mathrm{~T} / \mathrm{C}$ polymorphism in Fc $\in \mathrm{RI} \alpha$-chain promoter affecting the transcription activity: possible relationship to allergic diseases. J Immunol 2003;171:1927-33.

4. Potaczek DP, Sanak M, Mastalerz L, Setkowicz M, Kaczor M, Nizankowska E, et al. The $\alpha$-chain of high-affinity receptor for $\operatorname{IgE}(\mathrm{Fc} \in \mathrm{RI} \alpha)$ gene polymorphisms and serum IgE levels. Allergy 2006;61:1230-3.

Available online March 10, 2007 doi:10.1016/j.jaci.2007.01.030 